\title{
Effect of Incubation with Bacterial Extract on the Survival of X-irradiated Bacteria
}

\author{
By P. MUKHERJEE AND S. B. BHATTACHARJEE \\ Biophysics Division, Saha Institute of Nuclear Physics, \\ Calcutta-37, India
}

(Accepted for publication 28 December 1970)

\begin{abstract}
SUMMARY
X-irradiated Escherichia coli B, a filament-forming strain, showed improved survival of X-rays after treatment with its own extract, either in liquid or on solid media. Extract-promoted recovery was not shown by a non-filamentforming strain $E$. coli $\mathrm{B}_{\mathrm{s}-1}$. We failed to observe liquid holding recovery of $\mathrm{X}$-irradiated bacteria in the absence of extract. Most experiments were performed in liquid medium where the increased number of survivors depended on the incubation period and the extract concentration. In about $30 \mathrm{~min}$. the increase reached a saturation value; the maximum number of survivors was obtained using a certain (optimal) concentration of extract which was then employed in all subsequent experiments. The activity of the extract was completely destroyed by heating at $52^{\circ}$ for $40 \mathrm{~min}$. No activity was detected in the DNA, RNA or ribosomal fractions of the extract. The soluble remainder, however, was fully active, suggesting that soluble protein was the active principle.
\end{abstract}

\section{INTRODUCTION}

The recovery of bacteria from ultraviolet light-induced damage is well established (Jagger, I960; Castellani, Jagger \& Setlow, I964; Setlow, I966; Kantor \& Deering, 1967; Ganesan \& Smith, I968, I969). Recovery from X-ray-induced damage has also been reported, after suboptimal growth conditions (Alper \& Gillies, 1958, 1960), treatment with ribonuclease (Bhattacharjee, 1965), holding in buffer (Stapleton, Billen \& Hollaender, I953; Castellani, Magaudda \& Trezza, I968) and treatment with a bacterial extract (Adler, Fisher, Hardigree \& Stapleton, 1966; Fisher, Adler, Shull \& Cohen, 1969). Some authors found extract-promoted recovery only when the treatment was on an agar gel (Fisher et al. 1969), whereas others observed it only in liquid media (Korgaonkar \& Raut, 1967). No success has previously been reported in observing extract-promoted recovery both on solid and in liquid media for the same strain of irradiated bacteria.

In this paper, we show that recovery from X-ray-induced damage in Escherichia coli в was promoted by bacterial extract on agar plates as well as in liquid media and that the soluble part of the extract, probably protein, was responsible.

\section{METHODS}

Preparation of the bacterial suspensions. The filament-forming bacterial strain Escherichia coli $\mathrm{B}$ and a non-filament-forming radiation-sensitive derivative $E$. coli $\mathbf{B}_{\mathbf{3}-1}$ were routinely grown in the tris-glucose medium (Maaløe \& Hanawalt, I96I). An over- 
night culture was diluted 50 times with the same medium and grown with aeration at $37^{\circ}$. During the logarithmic phase the bacteria were collected by centrifugation, washed three times with ice-cold $\mathrm{Mr} 5$ phosphate buffer $(\mathrm{pH} \mathrm{6.8)}$ ) and resuspended in similar warmed buffer at between $10^{8}$ and $10^{9}$ organisms $/ \mathrm{ml}$. The X-ray sensitivity was unaffected by bacterial concentration within this range.

Preparation and estimation of cell components. Cell-free extract was obtained from protoplasts of Escherichia coli B formed by the penicillin method of Lederberg (1956) lysed in magnesium sulphate (O.0I $\mathrm{M}$ ) and centrifuged at $5000 \mathrm{rev} . / \mathrm{min}$. in the cold. The supernatant, called the total cell-free extract (TCFE), was collected. The concentration of the bacterial extract was arbitrarily estimated by determining its refractive index with the Abbe refractometer, assuming that the specific refractive increment was $\mathrm{I} .88 \times 10^{-3}$ decilitre/g., equivalent to that of protein. From time to time, fresh extract was prepared and its concentration determined as above.

DNA of Escherichia coli $\mathrm{B}$ in the native form was extracted by the method of Marmur (196I) and assayed with a modified Dische reaction (Burton, 1956), using depolymerized calf-thymus DNA as the standard. The extinction was observed at $600 \mathrm{~nm}$.

RNA was isolated by the phenol method from Escherichia coli B (Monier et al. 1962) and assayed at $660 \mathrm{~nm}$. by the orcinol reaction (Mejbaum, 1939) with yeast RNA as standard.

Protein was estimated at $750 \mathrm{~nm}$. by the method of Lowry, Rosebrough, Farr \& Randall (I95I) using lysozyme as standard. The DNA and RNA preparations contained below $3 \%$ protein.

TCFE after collection was centrifuged in a preparative ultracentrifuge at $92,739 \mathrm{~g}$ for I80 min. following the technique of Anraku (1966). The supernatant containing RNA, DNA and soluble protein was collected. Sediment containing ribosomes was resuspended in phosphate buffer containing $0.01 \mathrm{M}-\mathrm{MgSO}_{4}$. Both fractions were used for the treatment of irradiated bacteria.

The cell-fractions as well as TCFE were checked in each experiment for the presence of viable bacteria by plating $0.1 \mathrm{ml}$. If any visible colony was observed on such plates the experiments were rejected.

Irradiation of bacteria and determination of viable number. Bacteria were exposed to various doses of X-rays ranging from I to $24 \mathrm{krads}$ in a brass holder in a small Petri dish in contact with ice. The X-ray dose from a Muller MG 150 tube run at $80 \mathrm{kV}, 9 \mathrm{~mA}$, as measured by the method of $\mathrm{FeSO}_{4}$-dosimetry, was $6 \mathrm{krads} / \mathrm{min}$. Viable bacteria were determined by plating $0.1 \mathrm{ml}$. aliquots of suitable dilutions on the surface of nutrient agar plates and counting colonies after $18 \mathrm{~h}$. incubation at $37^{\circ}$. The initial viable titre of bacteria was determined from an non-irradiated sample.

Treatment of $X$-irradiated bacteria. Samples were usually divided into four parts after irradiation, each containing $\mathrm{I}$ ml. of suspension. To each of the tubes, TCFE at four different final concentrations $(997.5,1662.5,2660$ and $3325 \mu \mathrm{g} . / \mathrm{ml}$.) was added and the final volume was made up to $4 \mathrm{~cm} .^{3}$ by adding phosphate buffer. The suspensions were then shaken in a $37^{\circ}$ water-bath shaker for $2 \mathrm{~h}$. For comparison, irradiated cells were also held under conditions identical save for the absence of the bacterial extract. The number of viable bacteria was determined at $30 \mathrm{~min}$. intervals. Similar experiments were also done with native, denatured and renatured DNA, native RNA, and native DNA and native RNA mixed in the ratio in which they existed in bacteria, and with ribosomal and soluble (protein) fractions. 
For experiments with TCFE on plates, $0.1 \mathrm{ml}$. of X-irradiated suspension was spread after suitable dilution on agar plates in presence of TCFE. The concentration of TCFE was calculated as $\mu \mathrm{g}$. $/ \mathrm{ml}$. of the medium in the agar plate. In order to prevent any decrease in survival due to radiation-induced peroxides, catalase.was incorporated in all post-irradiation media at between 2 and $4 \mu \mathrm{g} . / \mathrm{ml}$.

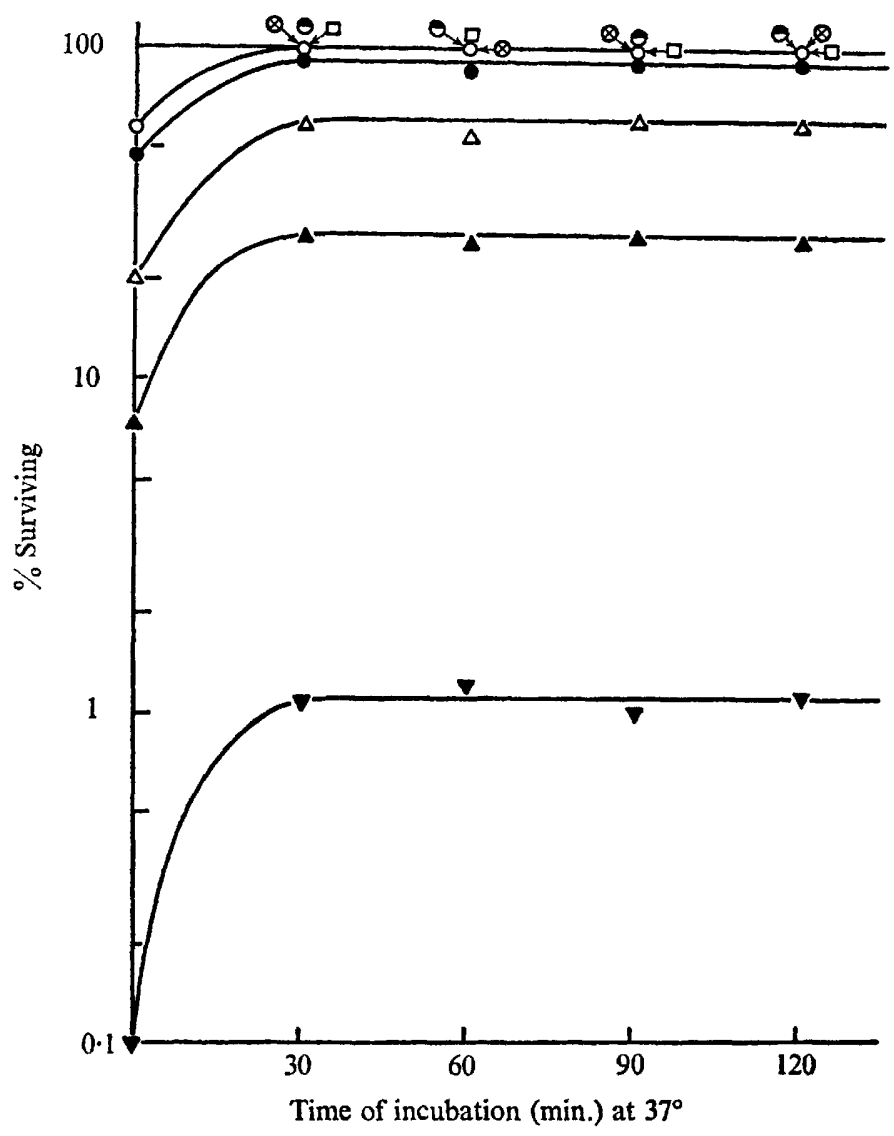

Fig. I. Change in viable count during incubation of bacteria in buffer. (a) Non-irradiated bacteria in presence of extract $(\otimes)$, catalase $(\theta)$, extract + catalase $(\square)$. (b) Irradiated bacteria in presence of extract + catalase at dose of radiation: $1 \mathrm{krad}(0), 1 \cdot 5 \mathrm{krads}(0), 3 \mathrm{krads}(\triangle)$, 6 krads (A), 12 krads ( $\nabla)$.

\section{RESULTS}

Fig. I shows the effect of holding X-irradiated and non-irradiated bacteria in the presence of total cell-free extract (TCFE) in buffer at $37^{\circ}$. This is a typical experiment in which extract was employed at a concentration (defined above) of $1662 \cdot 5 \mu \mathrm{g}$. $/ \mathrm{ml}$. Experiments at other concentrations gave broadly similar results and were used to construct the curves in Fig. 2. For bacteria irradiated with X-rays to the level of about $60 \%$ survival, an increase up to $100 \%$ viability was observed after $30 \mathrm{~min}$. incubation. At the $50 \%$ survival level, a maximum of $90 \%$ recovery was attained. Below the $40 \%$ survival level, however, there was much less recovery, and below $0.1 \%$ survival none at all. The maximum increase in survival level was reached after about $30 \mathrm{~min}$. incubation for all 
$\mathrm{X}$-ray doses, and for all the concentrations of TCFE used. Non-irradiated control bacteria did not show any change in viable count during incubation with the extract.

Fig. 2 shows the influence of the extract concentration on recovery. For all the doses of radiation there was an optimum concentration for recovery and this was used in the subsequent experiments. The time allowed for incubation was $r h$., which was sufficient for maximum recovery.

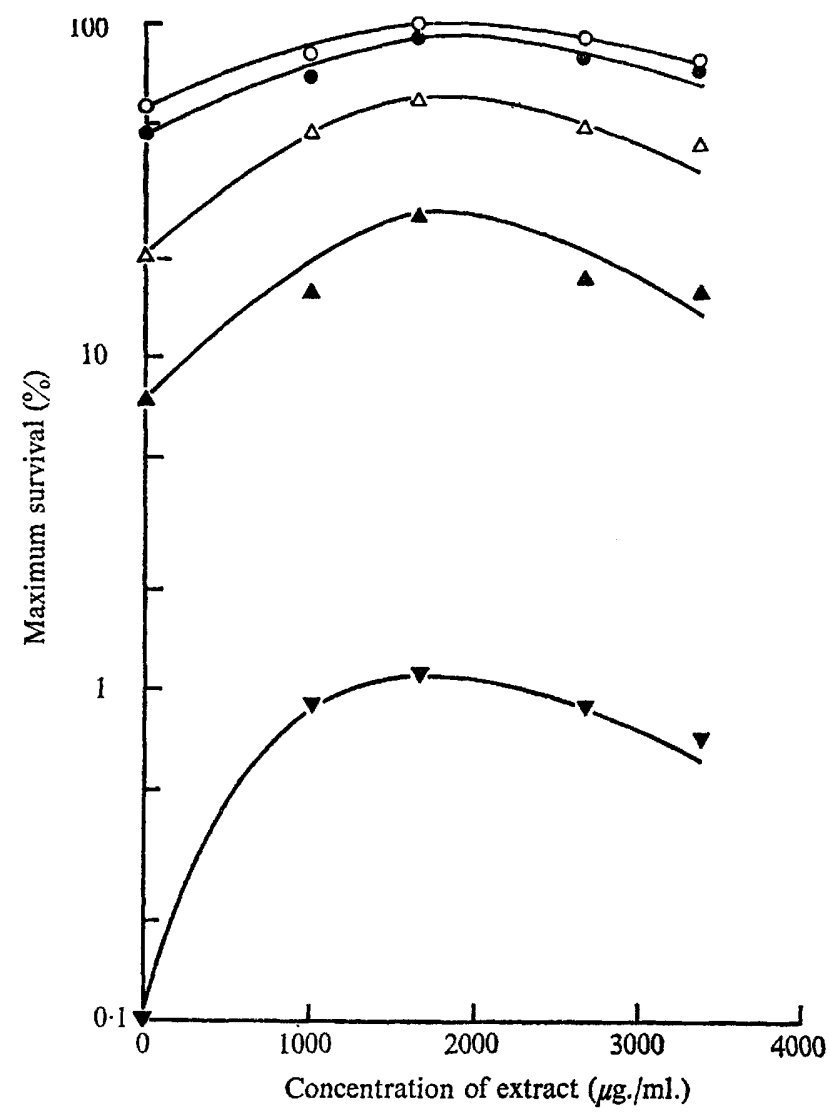

Fig. 2. Variation in the survival of irradiated bacteria after $\mathrm{r} \operatorname{krad}(0), 1.5 \mathrm{krads}(0), 3 \mathrm{krads}$ $(\triangle), 6 \mathrm{krads}(\Delta), 12 \mathrm{krads}(\nabla)$, during a $\mathrm{I} \mathrm{h}$. incubation with different concentrations of bacterial extract.

Table I. Liquid holding of X-irradiated Escherichia coli B cells in phosphate buffer

\begin{tabular}{|c|c|c|c|c|c|c|c|c|}
\hline \multirow{3}{*}{$\begin{array}{c}\text { Initial } \\
\text { X-ray } \\
\text { survival } \\
(\%)\end{array}$} & \multicolumn{8}{|c|}{$\%$ surviving after incubation period (min.) } \\
\hline & \multicolumn{4}{|c|}{ In presence of catalase } & \multicolumn{4}{|c|}{ In absence of catalase } \\
\hline & 30 & 60 & 90 & 120 & 30 & 60 & 90 & 120 \\
\hline $\begin{array}{l}57 \\
50\end{array}$ & $\begin{array}{l}57 \\
49 \cdot 6\end{array}$ & $\begin{array}{l}57 \cdot 5 \\
49 \cdot 8\end{array}$ & $\begin{array}{l}56 \cdot 8 \\
51\end{array}$ & $\begin{array}{l}57 \\
49\end{array}$ & $\begin{array}{l}52 \\
45\end{array}$ & $\begin{array}{l}5 \text { I } \\
44\end{array}$ & $\begin{array}{l}51 \cdot 8 \\
44 \cdot 8\end{array}$ & $\begin{array}{l}51 \cdot 5 \\
45 \cdot 2\end{array}$ \\
\hline 21 & $2 \mathrm{I}$ & $2 \mathrm{I}$ & $20 \cdot 5$ & $20 \cdot 8$ & 9.5 & IO & 10.5 & $9 \cdot 5$ \\
\hline $\begin{array}{l}7 \\
0.25\end{array}$ & $\begin{array}{l}7 \\
0.3\end{array}$ & $\begin{array}{l}7.2 \\
0.25\end{array}$ & $\begin{array}{l}7.5 \\
0.24\end{array}$ & $\begin{array}{l}6.8 \\
0.25\end{array}$ & $\begin{array}{l}2.7 \\
0.03\end{array}$ & $\begin{array}{l}2.5 \\
0.02\end{array}$ & $\begin{array}{l}3 \\
0.025\end{array}$ & $\begin{array}{l}2 \cdot 5 \\
0.025\end{array}$ \\
\hline
\end{tabular}


In order to test for the involvement of liquid-holding recovery, X-irradiated bacteria were held for $2 \mathrm{~h}$. at $37^{\circ}$ in phosphate buffer with or without catalase $(2 \mu \mathrm{g} . / \mathrm{ml}$.). Table I shows that $\mathrm{X}$-irradiated bacteria without catalase gave the usual peroxide death, which reached a maximum in about $\frac{1}{2} h$.; with catalase viability was constant for the whole period, in contrast to the observations of Castellani et al. (1968), which showed 'liquid-holding recovery'.

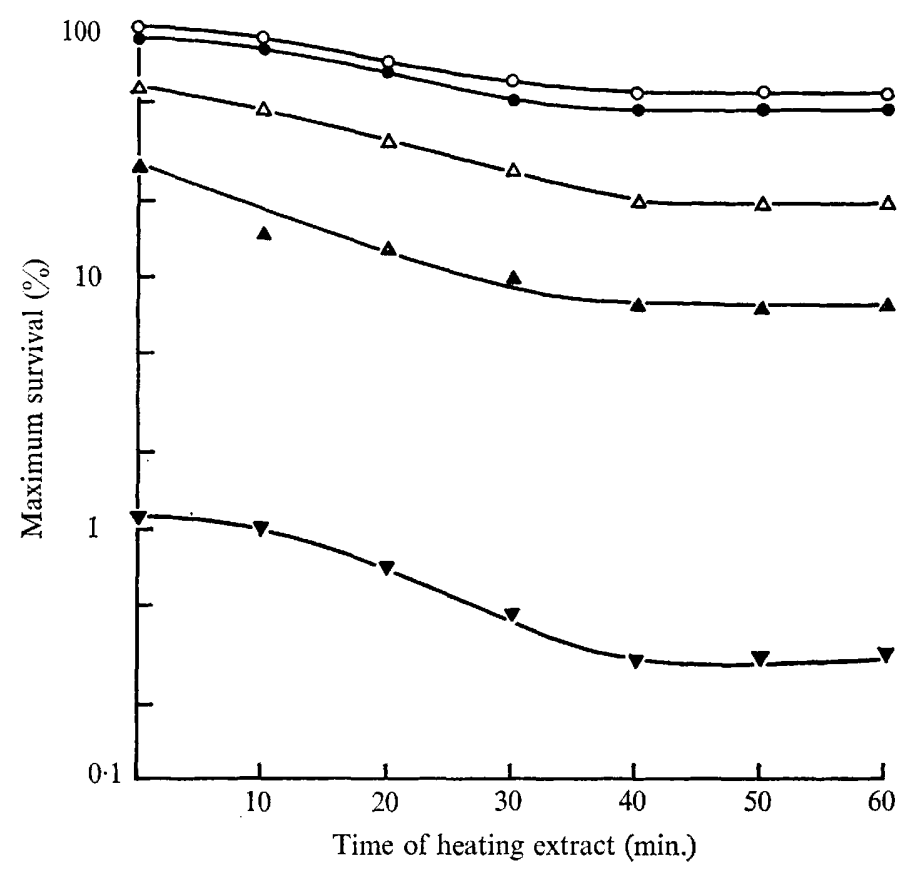

Fig. 3. Effect of heating the extract at $52^{\circ}$ on its ability to promote recovery after X-ray doses: I krad $(0), I \cdot 5$ krads $(\Theta), 3$ krads $(\triangle), 6$ krads $(\Delta)$ and 12 krads $(\nabla)$. Irradiated bacteria were incubated for $\mathrm{I} h$. with the optimum concentration of TCFE.

Table 2. Effect of extract of Escherichia coli $B$ on $X$-irradiated E. coli $B_{b-1}$ Initial X-ray survival (\%)

\begin{tabular}{cccc}
\multicolumn{4}{c}{$\%$ surviving after different periods of incubation (min.) } \\
\hline 30 & 60 & 90 & 120 \\
32 & 29 & 32 & $31 \cdot 5$ \\
20 & 18 & 21 & $20 \cdot 5$ \\
6 & 7 & $5 \cdot 8$ & $5 \cdot 8$ \\
0.4 & 0.35 & 0.30 & 0.32
\end{tabular}

The observed extract-promoted increase in X-ray survival shown in Fig. I was obtained with Escherichia coli $\mathrm{B}$ only. The same experiment repeated with $E$. coli $\mathrm{B}_{\mathrm{B}-1}$ (Table 2) showed no increase in viability on incubation of bacteria in buffer containing catalase $(2 \mu \mathrm{g} . / \mathrm{ml}$.) and/or the extract made from $E$. coli B. The experiment was performed with similar results for various extract concentrations, although results for only the optimum concentration, $1662.5 \mu \mathrm{g}$. $/ \mathrm{ml}$., are shown in Table 2.

Fig. 3 shows the effect of heating the extract on its ability to promote recovery. 


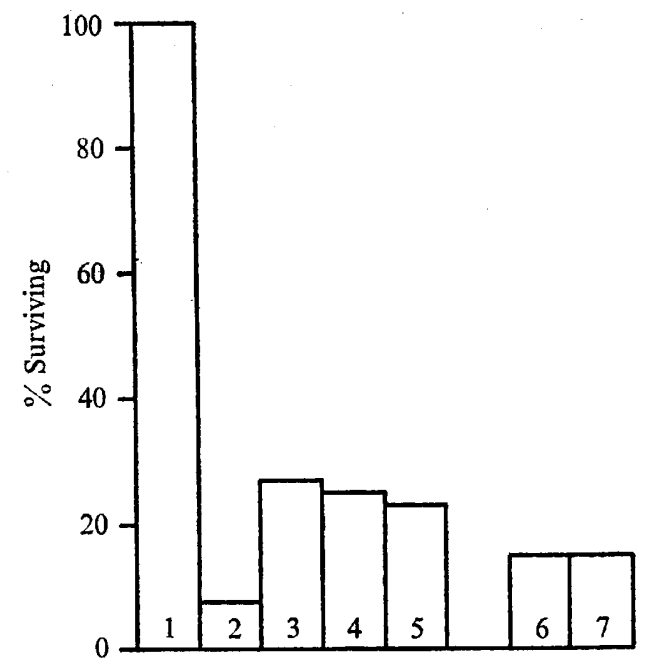

Fig. 4. Survival of X-irradiated bacteria in presence of extract in buffer and on plates. $I$, Initial viable bacteria; 2, X-ray survival in absence of extract; 3, X-ray survival after treatment with extract on plates; 4 , survival after $\mathrm{I}$ h. holding in buffer in presence of extract (plating without extract); 5 , plating of sample in 4 with extract; 6 , sample in 4 , washed and plated without extract; 7 , sample in 4 , washed and plated with extract.

Table 3. Effect of different cell constituents on post-irradiation recovery in buffer

\begin{tabular}{|c|c|c|c|c|c|}
\hline $\begin{array}{l}\text { Bacterial } \\
\text { titre/ml. }\end{array}$ & $\begin{array}{l}\text { X-ray } \\
\text { dose } \\
(\mathrm{krad})\end{array}$ & Treatment & $\begin{array}{c}\text { Concentra- } \\
\text { tion } \\
(\mu \mathrm{g} . / \mathrm{ml} .)\end{array}$ & $\begin{array}{c}\text { Survival on } \\
\text { immediate } \\
\text { plating } \\
(\%)\end{array}$ & $\begin{array}{c}\text { Survival } \\
\text { after I h. } \\
\text { incubation } \\
(\%)\end{array}$ \\
\hline $1.05 \times 10^{\circ}$ & $\begin{array}{l}1 \cdot 0 \\
1 \cdot 5\end{array}$ & $\begin{array}{l}\text { Native DNA } \\
\text { Native DNA }\end{array}$ & $\begin{array}{l}99 \\
99\end{array}$ & $\begin{array}{l}55 \\
49\end{array}$ & $\begin{array}{l}56 \\
49\end{array}$ \\
\hline $1.65 \times 10^{8}$ & 3 & Native DNA & 99 & 20 & $19 \cdot 3$ \\
\hline $1.93 \times 10^{8}$ & $\begin{array}{l}1 \cdot 0 \\
1 \cdot 5\end{array}$ & $\begin{array}{l}\text { Denatured DNA } \\
\text { Denatured DNA }\end{array}$ & $\begin{array}{l}99 \\
99\end{array}$ & $\begin{array}{l}54 \cdot 8 \\
46\end{array}$ & $\begin{array}{l}55^{\cdot 8} \\
46\end{array}$ \\
\hline $1 \cdot 19 \times 10^{8}$ & 3 & Denatured DNA & 99 & 21 & 20 \\
\hline $2 \cdot 27 \times 10^{8}$ & $\begin{array}{l}I \\
I \cdot 5\end{array}$ & $\begin{array}{l}\text { Renatured DNA } \\
\text { Renatured DNA }\end{array}$ & $\begin{array}{l}99 \\
99\end{array}$ & $\begin{array}{l}56 \cdot 2 \\
49 \cdot 8\end{array}$ & $\begin{array}{l}56 \cdot 8 \\
49\end{array}$ \\
\hline $1.65 \times 10^{8}$ & 3 & Renatured DNA & 99 & 20 & 20 \\
\hline $5.6 \times 10^{8}$ & $\begin{array}{l}I \\
1 \cdot 5\end{array}$ & $\begin{array}{l}\text { Native RNA } \\
\text { Native RNA }\end{array}$ & $\begin{array}{l}100 \\
100\end{array}$ & $\begin{array}{l}58 \\
47\end{array}$ & $\begin{array}{l}59 \\
46 \cdot 5\end{array}$ \\
\hline $4.65 \times 10^{8}$ & 3 & Native RNA & 100 & 19 & 19 \\
\hline $44 \times 10^{8}$ & $\mathbf{I}$ & Native (DNA \& RNA) & 40,80 & $58 \cdot 2$ & 57 \\
\hline $7.0 \times 10^{8}$ & $\begin{array}{l}1 \cdot 5 \\
3\end{array}$ & $\begin{array}{l}\text { Native (DNA \& RNA) } \\
\text { Native (DNA \& RNA) }\end{array}$ & $\begin{array}{l}40,80 \\
40,80\end{array}$ & $\begin{array}{c}48 \\
20 \cdot 5\end{array}$ & $\begin{array}{l}47 \cdot 5 \\
21\end{array}$ \\
\hline $1.67 \times 10^{9}$ & $\begin{array}{l}I \\
I \\
I \cdot 5 \\
I \cdot 5 \\
3 \\
3\end{array}$ & $\begin{array}{l}\text { Ribosomal protein } \\
\text { Soluble protein } \\
\text { Ribosomal protein } \\
\text { Soluble protein } \\
\text { Ribosomal protein } \\
\text { Soluble protein }\end{array}$ & $\begin{array}{l}80 \\
80 \\
80 \\
80 \\
80 \\
80\end{array}$ & $\begin{array}{l}62 \cdot 2 \\
62 \cdot 2 \\
50 \cdot 3 \\
50 \cdot 3 \\
19 \\
19\end{array}$ & $\begin{array}{l}62 \cdot 8 \\
100 \\
48 \cdot 5 \\
89 \cdot 8 \\
21 \cdot 5 \\
49\end{array}$ \\
\hline
\end{tabular}


Here for each X-ray survival level the maximum percentage of survivors that could be attained with untreated extract was considered to be the initial point. With the increase in heating time there was a systematic decrease in the maximum number of survivors that could be attained after incubation, until after $40 \mathrm{~min}$. or more there was no recovery at all.

Bacteria plated immediately after X-irradiation on nutrient agar plates in presence of TCFE showed an increase in survivors compared to those obtained without the extract (Fig. 4). The maximum effect was quantitatively similar to that shown in buffer for the same level of X-ray survivors. Bacteria first allowed to recover with TCFE in buffer and then washed did not show any subsequent effect of TCFE in the plating medium, suggesting that recovery in either liquid or on agar medium was probably due to the same cause.

Table 3 shows the results of holding the X-irradiated bacteria in buffer in the presence of different concentrations of various fractions of the TCFE. For the purpose of these experiments, the TCFE was considered to contain RNA, DNA, ribosomal protein and a soluble fraction (including soluble protein). It may be seen that no recovery occurred during incubation for $\mathrm{I} h$. in presence of DNA, native, denatured or in renatured form, RNA in native form, ribosomal protein, or DNA and RNA in the ratio in which they were present in bacteria (RNA:DNA, 2:I, dry wt; Setlow \& Pollard, 1962). Although Table 3 shows the result for only one concentration of the constituents, experiments with similar results were conducted with concentrations both below and above that given in the table. The soluble protein fraction, however, gave a clear and significant increase in number of survivors during incubation. The increase obtained with the optimal amount of soluble fraction was almost the same as that obtained with the total cell-free extract at its optimal concentration.

\section{DISCUSSION}

We believe that the increase in survival of X-irradiated Escherichia coli в observed with TCFE is the manifestation of a genuine recovery rather than division of surviving bacteria because of the following observations: (a) the presence of bacterial extract, catalase or both did not affect the survival of non-irradiated bacteria during incubation in phosphate buffer; $(b)$ heated extract was inactive; $(c)$ the increase in number of survivors of an X-irradiated bacterial population due to the presence of extract was the same in buffer or on an agar surface.

Adler $e$ t al. (1966) suggested that the extract-promoted restoration of X-ray-induced damage involved the division mechanism of bacteria. This is supported by our observation that Escherichia coli B, a filament-forming strain, showed the extract-promoted recovery, whereas $E$. coli $\mathrm{B}_{\mathrm{s}-1}$, a non-filament former, did not.

The results show that the active agent responsible for the increase in survival number was in the soluble fraction, possibly protein, although Adler and his associates thought that the activity might be associated with a large particle (Fisher et al. 1969). The removal of activity by heating at $52^{\circ}$ is consistent with, but does not prove, the involvement of protein. Treatment with RNA or DNA did not influence the survival number in any way, in agreement with Fisher et al. (1969), although highly polymerized DNA did promote recovery of X-irradiated Salmonella typhimurium (Kanazir, Cecuk, Krajcinovic \& Hudnik, 1959). 
An interesting aspect of the experiments was that there was an optimum concentration of TCFE above which recovery was reduced. Such an optimum concentration has also been reported by other experimenters (Korgaonkar \& Raut, 1967). Perhaps the enzymic balance in the extract was favourable only at the optimal concentration; below it the concentration of the active agent was too low, whereas above it some harmful enzymic activity was prominent. Another possibility is that some component of the extract at high concentrations inhibits the uptake of the active agent.

\section{REFEREN CES}

Adler, H. I., Fisher, W. D., Hardigree, A. A. \& Stapleton, G. E. (1966). Repair of radiationinduced damage to the cell division mechanism of Escherichia coli. Journal of Bacteriology 9I, 737-742.

AlPER, T. \& GILLIES, N.E. (1958). Restoration of Escherichia coli strain B after irradiation: its dependence on suboptimal growth conditions. Journal of General Microbiology 18, 46I-472.

ALPER, T. \& GILLIES, N. E. (1960). The relationship between growth and survival after irradiation of Escherichia coli strain в and two resistant mutants. Journal of General Microbiology 22, I1 3-1 28.

ANRAKu, Y. (1966). Cyclic phosphodiesterase of Escherichia coli. In Procedures in Nucleic Acid Research, p. 130. Edited by G. L. Cantoni \& D. R. Davies. New York and London: Harper and Row.

BHATTACHARJEe, S. B. (1965). Reactivation of radiation-killed E. coli with ribonuclease. Nature, London 207, 43I-432.

Burton, K. (1956). A study of the conditions and mechanism of the diphenylamine reaction for the colorimetric estimation of deoxyribonucleic acid. Biochemical Journal 62, 315-323.

CASTELlANI, A., JAGGER, J. \& SeTLOW, R. B. (1964). Overlap of photo-reactivation and liquid-holding recovery. Science, New York $\mathbf{4 3 3}$, I $170-1$ I 7 I.

Castellani, A., Magaudda, G. \& Trezza, G. (I968). Role of protein synthesis in the repair of ionization radiation damage. Nuclear Science Abstracts 22, 344I.

Fisher, W. D., Adler, H. I., Shull, F. W. Jun., \& Cohen, A. (1969). Properties of a cell fraction that repairs damage to the cell-division mechanism of Escherichia coli. Journal of Bacteriology 97, 500-505.

GANESAN, A. K. \& SMITH, K. C. (I968). Dark recovery processes in Escherichia coli irradiated with ultraviolet light. I. Effect of $\mathrm{rec}^{-}$mutations on liquid-holding recovery. Journal of Bacteriology 96, 365-373.

Ganesan, A. K. \& Smith, K. C. (1969). Dark recovery processes in Escherichia coli irradiated with ultraviolet light. II. Effect of uvr genes on liquid-holding recovery. Journal of Bacteriology $\mathbf{9 7}$, II 29-II33.

JAGGER, J. (1960). Photoreactivation. In Radiation Protection and Recovery, pp. 352-377. Edited by A. Hollaender. London: Pergamon Press.

Kanazir, D. T., CecuK, O. Z., Krajcinovic, B. N. \& Hudnik, T. A. (I959). The recovery of $\mathrm{X}$-irradiated Salmonella typhimurium by means of highly polymerized deoxyribonucleic acid. Bulletin of the Institute of Nuclear Sciences 'Boris Kidrich' 9, I33-I44.

KANTOR, G. J. \& DeERING, R. A. (1967). Recovery of division-ability in ultraviolet-irradiated Escherichia coli induced by photoreactivation, photoprotection and liquid-holding treatment. Journal of Bacteriology 94, 1946-1950.

KorgaONKAR, K. S. \& RAUT, S. L. (1967). Reactivation in u.v.-inactivated $E$. coli $\mathrm{K}$ I2 by cell-free extract. Currents in Modern Biology I, 29I-298.

LEDERBERG, J. (1956). Bacterial protoplasts induced by penicillin. Proceedings of the National Academy of Sciences of the United States of America 42, 574-577.

Lowry, O. H., Rosebrough, N. J., FarR, A. L. \& Randall, R. J. (I95I). Protein measurement with the folin phenol reagent. Journal of Biological Chemistry 193, 265-275.

MaAløE, O. \& Hanawalt, P. C. (196I). Thymine deficiency and the normal DNA replication cycle I. Journal of Molecular Biology 3, 144-I55. 
MARMUR, J. (196I). A procedure for the isolation of deoxyribonucleic acid from micro-organisms. Journal of Molecular Biology 3, 208-218.

MejBaum, W. Z. (1939). In Methods of Biochemical Analysis, vol, I, p. 298. Edited by D. Glick. New York: Interscience.

Monier, R., Naono, S., Hayes, D., Hayes, F. \& Gros, F. (I962). Studies on the heterogeneity of messenger RNA from E. coli. Journal of Molecular Biology 5, 31 I-324.

Setlow, R. B. \& Pollard, E. C. (1962). Molecular Biophysics, p. 16. Reading, Massachusetts: Addison-Wesley.

SeTLow, J. K. (1966). Current Topics in Radiation Research, vol. 2, pp. 195-248. Edited by M. Ebert \& A. Howard. Amsterdam: North Holland Publishing Company.

Stapleton, G. E., Billen, D. \& Hollaender, A. (I953). Recovery of X-irradiated bacteria at suboptimal incubation temperature. Journal of Cellular and Comparative Physiology 4r, 345-357. 